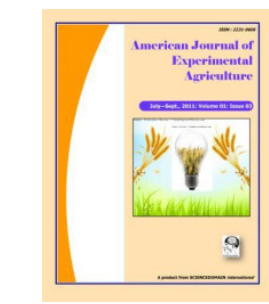

American Journal of Experimental Agriculture

1(4): 477-485, 2011

SCIENCEDOMAIN international

www.sciencedomain.org

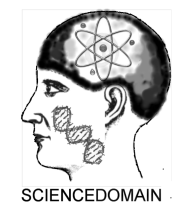

\title{
Assessment of the Performance of Sweet Potato Marketing System in South East Agro Ecological Zone, Nigeria
}

\author{
H. N. Anyaegbunam ${ }^{1^{\star}}$ and P. O. Nto ${ }^{2}$ \\ ${ }^{1}$ Extension Services Programme, National Root Crops Research Institute, Umudike, \\ PMB 7006; Umuahia, Abia State, Nigeria. \\ ${ }^{2}$ College of Agribusiness, Michael Okpara University of Agriculture Umudike, Abia State. \\ Nigeria.
}

Research Article

Received $20^{\text {th }}$ July 2011

Accepted $7^{\text {th }}$ September 2011 Online Ready $17^{\text {th }}$ November 2011

\section{ABSTRACT}

Aims: To determine the sweet potato marketing channel, gross marketing margin and returns, marketing efficiency and state the policy implications of the study.

Study design: Cross sectional study

Place and Duration of study: South east agro ecological zone of Nigeria, between January 2010- December 2010

Methodology: A multistage randomized sampling procedure was used in selecting 120 wholesalers, 240 retailers age range $35-45$ and then 24 markets respectively. Structured questionnaire was used to collect information from the respondents. Information collected bordered on volume and value of sales, cost of transportation and channel of distribution. Data were analyzed using marketing margin and Net-return analyses, Efficiency ratio, Chi square and Duncan multiple range tests.

Results: The study showed that sweetpotato marketing is not efficient but lucrative. This is as depicted by the results. Net margins realized were N14,632,N24,100,N24,600 and N28,603 on the wholesalers sector while N3,256,N5728,N5775 and N10,000 were realized on the retailers sector. Efficiency results revealed that none of the states/sectors had efficiency of $100 \%$. The efficiencies range $(20-80 \%)$. There were significant differences in marketing efficiencies in the markets across the states studied.

Conclusion: Lack of infrastructural facilities is the main problem militating against efficient marketing system in the zone under study. It is therefore, recommended that infrastructural facilities should be provided for the marketers to reduce spoilage and distressed sales. This will improve marketing efficiency. 
Keywords: Assessment; sweet potato; performance; marketing; efficiency and margin.

\section{INTRODUCTION}

Sweet potato (Ipomoea batata $(L) L a m$ ) is an important tropical root crop. It belongs to the morning-glory family known as convolulaceae and is originated from Latin America (Low et al., 2009). It ranks second after cassava among the tropical root crops. The crop can be considered promoting nutritional security particularly in agriculturally backward areas. Besides carbohydrates, it is a rich source of protein, lipid, calcium and carotene.

In view of the nutritional quality of sweetpotato, the crop constitutes a significant part of the diets of large number of people in the areas of production. It has been used in Africa to combat a widespread vitamin A deficiency that results in blindness and even death for 25,000-500,000 children a year (CIP, 2003).

Despite the demographic pressure on land, there has been an increase in the production of sweetpotato in Nigeria. Sweetpotato production rose from 2.516 million metric tones in 2006 to 3.4 million metric tones in 2007 (Akoroda, 2009, Srinivas, 2009). These increases were attributed to improved technological inputs, International and National research efforts.

Tewe et al. (2003) asserted that an increased sweetpotato production that is not marched by adequate promotion and marketing to absorb surpluses from increased yield has been detrimental to the sustainability of sweetpotato production in Nigeria.

Sweetpotato is seasonal and does not store for a long time. Poor storability of sweetpotato is mainly due to sprouting, dehydration and attack by pathogenic organisms (Ukpabi, 2004). These storage problems and others have led to losses by marketers in the course of performing their marketing functions.

In most cases, poor storability and seasonality lead to market variations in quantity and quality of roots and its associated price swings (Low et al., 2009). The rising consumer price for sweetpotato may be an indication of market inefficiency.

Marketing in developing countries such as Nigeria is beset with a lot of problems, which constitute a bottleneck to the flow of goods and services. Such problems include seasonal variations, transportation of harvested produce, storage, processing, grading and communication (Ikechi et al., 2006). These problems notwithstanding, sweetpotato production has been found to be profitable (Ogbonna et al., 2007).

Considering the increases experienced in sweetpotato production and the inability of the increases to be absorbed in the marketing system as stated earlier, Low et al. (2009) attributed the inefficiencies in the marketing system of sweetpotato to inadequacies of storage, processing, transportation and perishability. According to Onabanjo (2008) lack of good processing technology is one of the greatest problems militating against efficient sweetpotato marketing system. This is due to lack of diversification of the uses. On the basis of these problems, a variety of policy recommendations were made by Tewe et al., (2003). Notable among these were, provision of adequate storage, processing, marketing and transportation facilities. The question to be addressed is how efficient is the sweetpotato marketing system? or how well is the sweetpotato marketing system performing?. According 
to Arene (1999) efficiency is used to evaluate marketing performance. Performance can be achieved using the following approaches-marketing margin, Net-returns and marketing efficiency ratios. Therefore, there is the need to assess the performance of the market to determine the efficiency of the sweetpotato marketing system in south east agro ecological zone of Nigeria

Hypotheses Tested:

1) Sweetpotato marketing system in the zone is efficient

2) The level of marketing efficiency in the markets across the states do not differ significantly

\section{METHODOLOGY}

The study area was south east agro ecological zone of Nigria. It consists of nine states namely Abia, Akwa-lbom, Anambra, Cross River, Enugu, Imo, Rivers, Bayelsa and Ebonyi States. A multistage random sampling method was used in the selection of markets and respondents.

In the first stage, four states Anambra, Cross River, Ebonyi and Enugu were selected randomly out of the nine states. In the second stage, two zones were randomly selected in each of the chosen states; making it a total of eight agricultural zones. In stage three, three (one urban and two rural) markets were drawn from a list of markets in each of the eight selected agricultural zones Ten retailers and five wholesalers were randomly selected in stage four. A total sample size of 240 retailers and 120 wholesalers were drawn respectively.

A well structured questionnaire was used to elicit information from the respondents, information sought bordered on value of monthly purchases and sales, quantity sold and bought, cost of transportation and channels of distribution. Data were analyzed using marketing margin, marketing cost-return and marketing efficiency analyses. Chi square and Duncan multiple tests were used to test for significant differences.

\subsection{Marketing Margin (M.M.)}

This was calculated for wholesalers, and retailers adopting Mendoza (1995) formula:

Marketing margin $=\frac{\text { Selling price-supply price }}{\text { Selling price }} \times \frac{100}{1} \quad-\quad-$

\subsection{Net Returns}

According to Scarborough and Kydd (1992) the formula for marketing costs/net returns is mathematically stated as:

Where:

$$
\mathrm{NR}=\mathrm{TRS}-\mathrm{TMC} \quad-\quad-\quad-\quad-
$$

$\begin{array}{lll}\text { NR } & = & \text { Net returns } \\ \text { TRS } & = & \text { Total Revenue (or returns) from sales } \\ \text { TMC } & = & \text { Total Marketing Costs }\end{array}$




\subsection{Marketing Efficiency}

A simplified marketing efficiency ratio evaluation was used to determine the marketing efficiency as applied by Olukosi and Isitor (1990), and Ozougwu (2002)

$$
M . E=\frac{\text { Value added by marketing (net profit) }}{\text { Total marketing costs (TMC) }} \times \frac{100}{1}-
$$

Where: M.E. = Marketing Efficiency.

This could be said to mean the percentage ratio of price increase to costs of marketing. According to Scarborough and Kydd (1992), the value of marketing efficiency ranges from $0 \%$ to infinity. If marketing efficiency is $100 \%$ (unity), it shows that the market is perfectly efficient because price increment is just high enough to cover the cost of marketing such commodity. Whereas marketing efficiency that is greater than $100 \%$ indicates excess profit. However, if marketing efficiency less than $100 \%$ is an indication of inefficiency.

\subsection{Chi Square Test Statistics}

It was used to test whether there was a significant difference in marketing efficiency in the four chosen states for wholesalers and retailers separately. Chi square is given by:

$$
\mathrm{X}^{2}=\Sigma\left[(\mathrm{Oi}-\mathrm{E})^{2} / \mathrm{Ei}\right] \text { with } \mathrm{n}-1 \text { degree of freedom }(\mathrm{df}) \quad-\quad-\quad-
$$

Where $\mathrm{X}^{2}=$ Chi square

$\mathrm{Oi}=$ Observed ith value

$\mathrm{Ei}=$ Expected ith value

$\mathrm{n}=$ number of states compared

In this case, four states were compared, thus $n-1$ (df) $=3$ The expected for marketing efficiency was $100 \%$. The null hypothesis was rejected if the Chi-Square computed was greater than the tabulated value at $5 \%$. Duncan's multiple range tests was also used to confirm differences in efficiencies among the states.

\section{RESULTS AND DISCUSSION}

\subsection{Sweetpotato Marketing Channel}

The distribution or marketing of sweetpotato operates through the activities of many middlemen who operate in both rural and urban markets. The marketing channel shows the different (alternate) routes through which sweetpotato passes from the producer to the final consumer. The marketing channel for sweetpotato is shown in Figure 1. The sweetpotato marketing channels in the zone are made up of single and multi-stage channels. The single channel consists of the flow of sweetpotato from the producer to the consumer directly without any intermediary, that is, the producer or the farmer sells directly to the consumer. The second channel, which is the multistage channel system, consists of middle men, that is, sweetpotato has to pass a number of intermediaries before it gets to the final consumer.

The multistage channel system is made up of the sweetpotato producer/farmer, country assemblers, the urban and rural wholesalers and then the retailers (major links). All these 
categories of intermediaries are not exclusive because the producer can decide to sell directly to the wholesalers and retailer (minor flow/links), (Tewe et al., 2003). According to Adekanye (1988), in Nigeria it is difficult to ascertain who is a wholesaler or retailer in the market. This is because some distributors are engaged in both wholesaling and retailing activities at the same time and place. However, categorization of wholesalers and retailers are based on the quantity and more pronounced activity a wholesaler or retailer does. The implication of multiple channel system is that as commodities pass through many intermediaries, it tends to increase marketing costs which will be borne by the consumers.

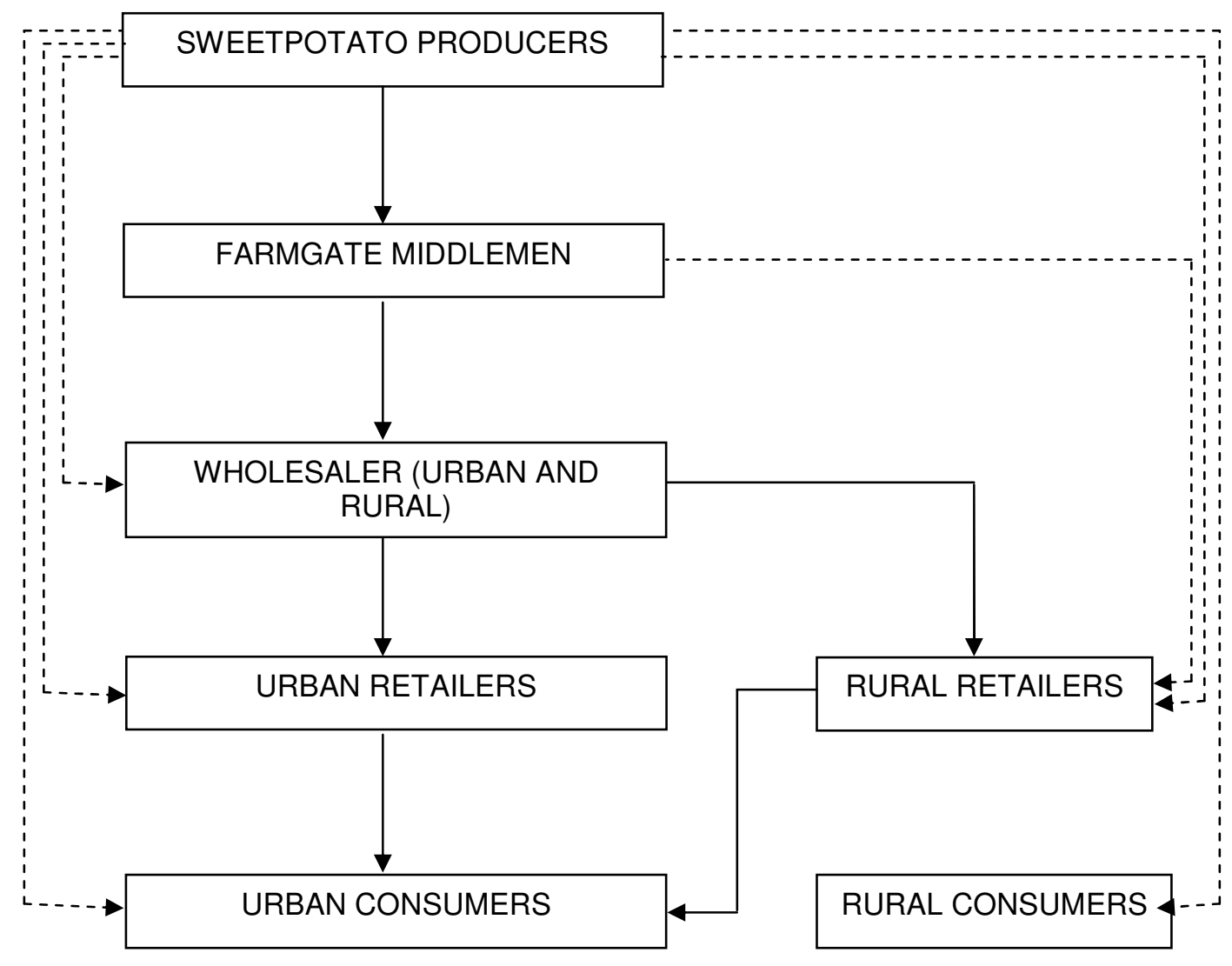

Fig 1: Sweet potato marketing channels in south-east agro-ecological zone.

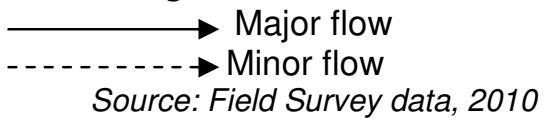

\subsection{Gross Marketing Margin, Returns and Efficiency}

Tables 1 and 2 show the net returns marketing margin and efficiency analyses of wholesalers and retailers, respectively. Table 1 shows that average monthly net returns from sales of the wholesalers in the four states are (A)14,632; (\$)24,100; (A)24,600 and (\$) 28,603 for cross river, Enugu, Ebonyi and Anambra states respectively while the retailers monthly average net returns are shown in table 2. They are as follows (N) 3, 256; ( $N$ ) 5, 728; 
(N) 5, 575 and (N) 10, 000 for Cross River, Enugu, Ebonyi and Anambra states respectively. The results showed that sweetpotato marketing is lucrative.

According to Scaborough and Kydd (1992) five percent and ten percent marketing margins are acceptable for storable and perishable goods. But the results of the Gross marketing margin of both the wholesalers and retailers were high and exceeded the tolerable levels of $10 \%$ marketing margin for perishable crops. This is an indication of excess profits.

Table 1: Net - returns, marketing margin and efficiency for wholesalers

\begin{tabular}{|c|c|c|c|c|}
\hline Items & $\begin{array}{l}\text { Cross River } \\
\text { state }\end{array}$ & $\begin{array}{l}\text { Enugu } \\
\text { state }\end{array}$ & $\begin{array}{l}\text { Ebonyi } \\
\text { state }\end{array}$ & $\begin{array}{l}\text { Anambra } \\
\text { state }\end{array}$ \\
\hline Average purchasing price per $\mathrm{kg}(\mathrm{N})$ & 21.68 & 12,41 & 21.35 & 10.49 \\
\hline Average selling price per $\mathrm{kg}(\mathrm{A})$ & 30.24 & $19-00$ & $30 \prime 15$ & 1921 \\
\hline Gross marketing margin $(\mathrm{N})$ & 14.84 & 6.59 & $8 ' 80$ & 8.72 \\
\hline Gross marketing margin (\%) & 49.07 & 34.00 & 29.19 & 45.39 \\
\hline Average return from sales $(\mathbb{A})$ & 58,932 & 74,224 & 90,103 & 83,603 \\
\hline Average marketing costs $(\mathbb{A})$ & 44,300 & 50,124 & 65,503 & 55,000 \\
\hline Net returns $(\mathbb{A})$ & 14,632 & 24,100 & 24,600 & 28,603 \\
\hline Marketing efficiency (\%) & 33.03 & 48.08 & 37.35 & 52.01 \\
\hline
\end{tabular}

Source: Field Survey data, 2010

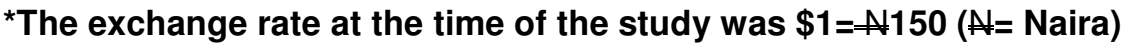

The marketing efficiencies for the wholesalers and retailers were low. Marketing efficiency ranges zero $(0)$ to infinity, $100 \%$ indicates perfectly efficient market and marketing efficiency less than $100 \%$ is an indication of marketing inefficiency (Scarborough and Kydd, 1992; Olukosi and Isitor 1990; Ozougwu, 2002). The results of the marketing efficiency show that the wholesalers have efficiencies of $33.03 \%, 48.08 \% ; 37.35 \%$, and $52.01 \%$, respectively while the retailers' marketing efficiencies are $22.95 \%, 56.6 \%, 50.22 \%$ and $86.33 \%$, respectively. These figures are all less than $100 \%$ and therefore the market is inefficient. But the retailers have better marketing efficiency than the wholesalers.

Table 2: Net - returns, marketing margin and efficiency for retailers

\begin{tabular}{lcccc}
\hline Items & $\begin{array}{c}\text { Cross river } \\
\text { state }\end{array}$ & $\begin{array}{c}\text { Enugu } \\
\text { state }\end{array}$ & $\begin{array}{c}\text { Ebonyi } \\
\text { state }\end{array}$ & $\begin{array}{c}\text { Anambra } \\
\text { state }\end{array}$ \\
\hline Average purchasing price per $\mathrm{kg}((\mathrm{N})$ & 30.24 & 19.00 & 30.15 & 19.21 \\
Average selling price per kg $((\mathrm{N})$ & 37.31 & 24.41 & 36.61 & 29.63 \\
Gross marketing margin $(\mathrm{N})$ & 7.07 & 5.41 & 6.46 & 10.42 \\
Gross marketing margin (\%) & 18.91 & 22.00 & 17.65 & 35.17 \\
Average return from sales (N) & 17,506 & 21,378 & 16,675 & 20,819 \\
Average marketing costs (N) & 14,250 & 13,650 & 11,100 & 18,819 \\
Net returns (N) & 3,256 & 57.28 & 5,575 & 10,100 \\
Marketing efficiency (\%) & 22.85 & 56.61 & 50.22 & 86.33 \\
\hline
\end{tabular}

Source: Field Survey data, 2010

Anambra state has higher marketing margin and efficiency than other states. This is because almost all the Agricultural zones. Anambra state produces sweetpotato in large quantities. This induces marketers from neighboring states like Imo, Abia and Enugu states 
to buy sweetpotato from the state. Again, retailers have higher marketing efficiency than wholesalers as depicted from tables 1 and 2 respectively. This is because of reduced marketing costs and profit made per unit product by the retailers. Therefore, since none of the markets (both wholesale and retail) had marketing efficiency of $100 \%$, we reject the null hypothesis which states that sweetpotato market is efficient. The efficiency and net -return results obtained in this study were in agreement with earlier works on some agricultural products like palm oil carried out, Oluwadare and Imoudu (2000). The entire results indicated inefficiency and attainment of high margin.

\section{*The exchange rate at the time of the study was $\$ 1=\mathrm{N} 150$ ( $\mathrm{N}=\mathrm{Naira})$}

Chi square $\left(\mathrm{X}^{2}\right)$ test statistic was used to test whether there is significant difference in marketing efficiency in the four states under study. The result is stated as follows:

$\mathrm{X}^{2}$ calculated (for wholesalers) $=134.09$

$\mathrm{X}^{2}$ calculated (for retailers) $=105.00$

$\mathrm{X}^{2}$ tabulated at $5 \%=7.82$

Since $X^{2}$ calculated is higher than $X^{2}$ tabulated for both the wholesalers and retailers; we reject the null hypothesis which states that the marketing efficiency in the four states is not significantly different and accept the alternate hypothesis of significant difference in the marketing efficiencies in the four states

Table 3: Duncan's multiple range test for marketing efficiency (Wholesalers)

\begin{tabular}{llll}
\hline Duncan Grouping & Mean (ME) & N & States \\
\hline A & 48.08 & 31 & Enugu \\
A & 52.01 & 31 & Anambra \\
B & 33.03 & 29 & Cross River \\
B & 37.35 & 29 & Ebonyi \\
Source: Field Survey data, 2010 & & \\
ME $=$ Marketing Efficiency & & &
\end{tabular}

The result was further subjected to analysis of variance (ANOVA) test using Duncan's multiple range test to confirm the differences in marketing efficiencies among states. These are shown in tables 3 and 4 for wholesalers and retailers respectively. The ANOVA detected differences in marketing efficiency of the wholesalers among the states as shown in table 3. Enugu and Anambra states were in the same group (A), they had close marketing efficiency while Cross River state and Ebonyi states were also in the same group (B). Therefore, conclusion was made that there were differences in marketing efficiencies among the states.

Table 4: Duncan's multiple range test for marketing efficiency (Retailers)

\begin{tabular}{llll}
\hline Duncan grouping & Mean (ME) & $\mathbf{N}$ & States \\
\hline A & 86.33 & 61 & Anambra \\
B & 50.22 & 61 & Ebonyi \\
C & 22.85 & 62 & Cross River \\
B & 56.61 & 59 & Enugu \\
\hline
\end{tabular}

Source: Field Survey data, 2010

ME=Marketing Efficiency 
For the retailers as shown in table 4, Anambra fell on group (A) and had the highest marketing efficiency while Ebonyi and Enugu states appeared on group B having similar marketing efficiency. Cross River was on a different group (C) and had the lowest marketing efficiency.

This result also confirmed the differences in marketing efficiencies among the states under study. It is concluded that there was significant difference in marketing efficiency among the states - Cross River, Ebonyi, Anambra and Enugu, both on the wholesalers and retailers sectors.

\section{CONCLUSION}

The results of the study depicted that there are imperfections in the marketing system as revealed by the performance evaluation. It showed that sweetpotato marketing system is not efficient; but lucrative. Then efforts should be made to diversify sweetpotato uses to reduce spoilage, market glut and improve efficiency. Infrastructural facilities should be made available for the marketers.

\section{COMPETING INTERESTS}

Authors have declared that no competing interests exist.

\section{REFERENCES}

Akoroda, M. (2009). Sweetpotato in West Africa 'In' The Sweetpotato. Loebenstein G and G. Thottapilly (eds) Spring science Business media B. V., 2009. 456-457.

Arene, C.J. (1999). Introduction to Agricultural Marketing Analyses for Developing Economics. Fulladu Publishing Company, Nsukka, 15-23.

CIP (International Potato Centre) Lima, Peru. (2003). Sweetpotato: Treasure for the power in sweetpotato main. 25.

FAOSTAT. (2008). Food and Agricultural Organization of the United Nations. Production Statistics.

Ikechi, K., et al. (2006). The performance of vegetable production and marketing in Aba area, Abia State. Proceedings of the $40^{\text {th }}$ conference of Agricultural Society of Nigeria, held in Umudike. Abia State, 133-134.

Low, J., et al. (2009). Sweetpotato in Sub-Saharan Africa 'In' The sweetpotato., 7-9.

Ogbonna, M.C., et al. (2007). Profitability in the use of sweetpotato crop as soil conservation strategy in Umudike, Abia State, Nigeria. Scientific Research Journals and Essays, 2(10), 462-464. Available online at http:/www.academicjournals.org/SRE.

Olukosi, J.O., Isitor, S.U. (1990). Introduction to Agricultural Marketing and Prices. Principles and Applications. Abuja, Federal Capital Territory, Nigeria, G.U. Publications.

Oluwadare, O. S., Imoudu, O. (2000). Efficiency Measurement of Palm Oil Marketing in Ekiti State of Nigeria. African Journal of Business and Economic Research, 1(2), 7- 42.

Onabanjo, A. O. (2008). Post-harvest Handling, Storage, Processing and Utilization of sweetpotato in Nigeria. 'In' M. Akoroda and I. Egeonu (eds.). Proceedings of the first National Sweetpotato Conference held at University of Ibadan from $16^{\text {th }}-18^{\text {th }}$ September. 
Ozougwu, F.C. (2002). Economic Analysis of Rice Marketing Margin among participants in the marketing channel of rice in Adani in Uzo Uwani Local Government Area. M. Sc. Thesis, Department of Agricultural Economics, University of Nigeria, Nsukka.

Scarborogh, V., Kydd, J. (1992). Economic Analysis of Agricultural Markets: A manual. Chatham, UK: Natural Resources Institute, ODA, 166p.

Srinivas, T. (2009). Economics of Sweetpotato Production and Marketing. 'In' The Sweetpotato. Loebenstein G. and Thottapilly, G. (eds). Spring Science Business Media. B.V. 2009, 436-247.

Tewe, O.O., et al. (2003). Sweetpotato Production, Utilization and marketing In Nigeria. Lima Peru. International Potato centre (CIP) and the University of Ibadan. 54p.

Ukpabi, U.J. (2004). Sustainable Post harvest Technologies for the major Food Crops and Flesh. Paper presented at the workshop for Abia State Local Government Agricultural Officers. Held at National Root crops Research Institute Umudik10 $10^{\text {th }}-12^{\text {th }}$ May 2004.

(c) 2011 Anyaegbunam \& Nto; This is an Open Access article distributed under the terms of the Creative Commons Attribution License (http://creativecommons.org/licenses/by/3.0), which permits unrestricted use, distribution, and reproduction in any medium, provided the original work is properly cited. 